\title{
Identification of bacterial and fungal components in tobacco and tobacco smoke
}

\author{
Lennart Larsson*1, Bogumila Szponar², Beston Ridha1, Christina Pehrson ${ }^{1}$, \\ Jacek Dutkiewicz ${ }^{3}$, Ewa Krysińska-Traczyk ${ }^{3}$ and Jolanta Sitkowska ${ }^{3}$
}

Address: ${ }^{1}$ Department of Laboratory Medicine, Lund University, Lund, Sweden, ${ }^{2}$ Institute of Immunology and Experimental Therapy, Polish Academy of Sciences, Wroclaw, Poland and ${ }^{3}$ Department of Occupational Biohazards, Institute of Agricultural Medicine, Lublin, Poland

Email: Lennart Larsson* - lennart.larsson@med.lu.se; Bogumila Szponar - szponar@iitd.pan.wroc.pl; Beston Ridha - shadbeston@hotmail.com; Christina Pehrson - christina.pehrson@med.lu.se; Jacek Dutkiewicz - dutkiewi@galen.imw.lublin.pl; Ewa Krysińska-

Traczyk - ekt@galen.imw.lublin.pl; Jolanta Sitkowska - jolasitkowska@o2.pl

* Corresponding author

Published: 31 July 2008

Tobacco Induced Diseases 2008, 4:4 doi:10.1186/1617-9625-4-4

This article is available from: http://www.tobaccoinduceddiseases.com/content/4/I/4

(c) 2008 Larsson et al; licensee BioMed Central Ltd.

This is an Open Access article distributed under the terms of the Creative Commons Attribution License (http://creativecommons.org/licenses/by/2.0), which permits unrestricted use, distribution, and reproduction in any medium, provided the original work is properly cited.
Received: 12 June 2008

Accepted: 3I July 2008

\begin{abstract}
The microbiological composition of tobacco products was studied using culture and chemical analysis (of tobacco leaves) or chemical analysis only (tobacco and tobacco smoke). The chemical analyses utilized gas chromatography-tandem mass spectrometry for determining 3-hydroxy fatty acids, muramic acid, and ergosterol as markers of respectively lipopolysaccharide (LPS), peptidoglycan, and fungal biomass. Mesophilic bacteria dominated in both fresh and cured tobacco leaves; a range of additional bacteria and fungi were also found albeit in minor amounts. The peptidoglycan and LPS concentrations were approximately the same in tobacco leaves as in cigarette tobacco. The concentrations of the measured microbial components were much lower in some cigarettes locally produced in China, Korea, and Vietnam than in cigarettes of international brands purchased in the same countries, and the concentrations in the smoke were in general agreement with the concentrations in cigarette tobacco. No differences in microbial load in tobacco of "light" and "full flavor" cigarettes were seen. Storing cigarettes at high humidity resulted in elevated levels of fungi in the cigarette tobacco leading to increased ergosterol concentrations in the smoke. The fact that tobacco smoke is a bioaerosol may help to explain the high prevalence of respiratory disorders among smokers and non-smokers exposed to second hand smoke since the same symptoms are also commonly associated with exposure to bioaerosols.
\end{abstract}

\section{Introduction}

Many hundreds of compounds known to contribute to disease development have been identified in tobacco smoke. Both active and second hand smoking causes cancer and a multitude of other diseases such as for example chronic bronchitis and asthma. Three studies [1-3] have revealed that tobacco smoke contains endotoxin (lipopolysaccharide, LPS), a family of inflammatory toxins from
Gram-negative bacteria known to cause respiratory disease upon inhalation [4]. Hasday et al. [1] found that the amounts of endotoxin in tobacco were comparable with those of some other agricultural products. While Hasday et al. [1] used a Limulus method for measuring endotoxin, Larsson et al. [2] introduced gas chromatography-tandem mass spectrometry (GC-MSMS) for demonstrating 3hydroxytetradecanoic acid, a unique LPS constituent [5], 
in cigarette tobacco and smoke. GC-MSMS is a very specific analysis method for unequivocal identification of LPS. Sebastian et al. [3], using the same GC-MSMS method, demonstrated a linear relationship between the number of cigarettes smoked over a 5-h period indoors and air concentrations of endotoxin. Whether bioactive microbial compounds other than LPS, such as for example peptidoglycan and various fungal components, are present in cigarette smoke is not known from the literature.

An integrated method for characterizing microbial composition in environmental samples by GC-MSMS has been developed at our laboratory [6]. The method includes a protocol for preparation and analyzing samples for LPS markers 3-hydroxy fatty acids (3-OH FAs) of 10 18 carbon chain lengths, peptidoglycan marker muramic acid (MuAc), and fungal biomass marker ergosterol (Erg). In the present study a modified version [7] of this method was used for 1) measuring 3-OH FAs, MuAc, and Erg in tobacco from cigarettes of international as well as local brands purchased in different countries in Europe and Asia including "light" and "full flavor" cigarettes; 2) analysing the microbiological composition of tobacco leaves during different stages of curing by using both cultivation and determination of 3-OH FAs, MuAc, and Erg; 3) comparing the concentrations of the mentioned microbial markers in cigarette tobacco and smoke.

\section{Materials and methods Tobacco and smoke}

Tobacco of cigarettes from altogether 37 packs purchased in different cities in Europe and Asia were studied including i) "light" (1 pack/city) and "full flavor" (1 pack/city) cigarettes of a well-known international brand purchased in Wroclaw, Lund, Shanghai, Seoul, and Hanoi, ii) cigarettes of other different international brands (Wroclaw 3, Lund 4, Shanghai 1, and Seoul 2 packs, respectively) and iii) popular cigarettes of local origin (Wroclaw 3, St. Petersburg 3, Shanghai 3, Seoul 3, and Hanoi 5 packs, respectively).

Tobacco of "full flavor" cigarettes of the same international brand was analysed after the cigarettes had been stored at $54 \%, 75 \%$, and $94 \%$ relative humidity (RH), each at $20^{\circ} \mathrm{C}$ and $30^{\circ} \mathrm{C}$ during 2,8 , and 21 days. Saturated solutions of respectively $\mathrm{Mg}\left(\mathrm{NO}_{3}\right)_{2}, \mathrm{NaCl}$, and $\mathrm{KNO}_{3}$ were used for achieving the desired $\mathrm{RH}$ [8]; the cigarettes were stored in closed 1-L glass vials without any direct contact with the respective salt solution.

Tobacco and smoke of cigarettes were analysed after the tobacco had been enriched with bacteria and fungi. In brief, tobacco was removed from 12 "full flavor" cigarettes of an international brand. A suspension $(5 \mathrm{ml})$ of $E$. coli
(ATCC 25922) that had been cultivated for 3 days at $37^{\circ} \mathrm{C}$ on trypticase soya agar (TSA) was added to 6 of the tobacco portions; sterile water $(5 \mathrm{ml})$ was added to remaining 6 portions (controls). The tobacco was dried at room temperature for $72 \mathrm{~h}$. Then, 6 of the tobacco portions ( 3 bacteria-enriched portions and 3 controls) were analysed for 3-OH FAs and MuAc whereas the remaining 6 portions were used to prepare new cigarettes, the smoke of which was analysed for 3-OH FAs and MuAc (thus, 3 smoke samples from bacteria-enriched tobacco and 3 from the controls). In addition, tobacco and smoke from cigarettes that had been stored for 8 and 21 days at $94 \%$ $\mathrm{RH}$, the latter cigarettes visibly colonized by molds (see below), were analysed for Erg. The methods used for generating the smoke and collecting the mainstream smoke particles on Teflon filters have been described elsewhere [2].

\section{Tobacco leaves}

Fresh (F-1) tobacco leaves (light Burley) were collected from a plantation in southern Poland. Leaves from the same plantation were also taken after different time periods of air drying outdoors: for $2 \mathrm{wk}$ (F-2), $6 \mathrm{wk}$ (F-3), and $>6 \mathrm{wk}$ (F-4) viz. just before the leaves were shipped to the tobacco manufacturing plant. In addition, samples of airdried light Burley (B), fire-dried light Virginia (V), airdried and smoked dark Kentucky (K), and air-dried dark Skroniowski Mocny (SM) tobacco material were obtained from a manufacturing plant in eastern Poland in the forms of air-dried leaves (2007 harvest; stage 1), after curing (2007 harvest; stage 2), and after curing and storage > 1 year (2006 harvest; stage 3).

Cultivation was performed according to Skórska et al. [9]. In brief, chopped plant material ( $1 \mathrm{~g}$ ) was suspended in $100 \mathrm{ml}$ of saline with $0.05 \%$ Tween 80 , and after shaking, serial 10 -fold dilutions were made. $0.1-\mathrm{ml}$ aliquots of each dilution were spread on duplicate sets of different agar media. Blood agar was used for cultivating mesophilic Gram-negative and Gram-positive bacteria, eosin methylene blue (EMB) agar (Merck, Darmstadt, Germany) for cultivating Gram-negative bacteria, halfstrength TSA (Sigma, St. Louis, MO, USA) for cultivating thermophilic actinomycetes, and malt agar (Difco, Detroit, MI, USA) for cultivating fungi. The blood agar plates and $\mathrm{EMB}$ agar plates were incubated for 1 day at $37^{\circ} \mathrm{C}$, then 3 days at $22^{\circ} \mathrm{C}$, and finally 3 days at $4^{\circ} \mathrm{C}$. The malt agar plates were incubated for 4 days at $30^{\circ} \mathrm{C}$ and 4 days at $22^{\circ} \mathrm{C}$. The prolonged incubation at lower temperatures aimed to isolate as wide a spectrum of bacteria and fungi as possible. The TSA plates were incubated for 5 days at $55^{\circ} \mathrm{C}$. Colonies were counted and differentiated and the data reported as CFU/g tobacco. The bacteria were identified by using the API 20E, NE (bioMérieux, Marcy l'Etoile, France), and BIOLOG (Biolog, Inc., Hayward, CA, 
USA) systems. The fungi were identified by using microscopy [9].

\section{Chemical analysis}

Cigarette tobacco, tobacco leaves, and smoke particles (collected on Teflon filters) were dried, weighed, and subjected to hydrolysis. The entire hydrolysates of the particle-containing Teflon filters, a 1/50th fraction of each 200-300 mg tobacco leave hydrolysate sample, and a 1/ 100th fraction of each cigarette hydrolysate sample were further prepared for GC-MSMS analysis of 3-OH FAs, MuAc, and Erg as described previously $[6,7]$. Numbers of moles of LPS were calculated by summarizing the number of moles of the 3-OH FAs and dividing by 4 [6].

\section{Statistical analysis}

Independent Student's t-test (STATISTICA 7.1 software, StatSoft, USA) was used; $\mathrm{p}$ value $<0.05$ was considered as significant.

\section{Results \\ Tobacco}

LPS (5.7 - 21.0 pmol/mg), MuAc (1.4 - $10.7 \mathrm{ng} / \mathrm{mg})$, and $\operatorname{Erg}(0.3-12.8 \mathrm{ng} / \mathrm{mg})$ were detected in the tobacco of all of the studied cigarettes. Cigarettes of local brands purchased in China contained significantly less of MuAc and Erg than did cigarettes of international brands purchased in the same stores. Analogously, local cigarettes purchased in Korea contained less Erg than international brands, and local cigarettes purchased in Vietnam contained less LPS and Erg than international brands (Table 1).

There were no statistically significant differences between the microbial marker contents of "light" and "full flavor" cigarettes of the same international brand purchased in the five different countries (Table 2).

Storing the cigarettes at 54 and $75 \%$ RH did not affect the tobacco marker composition. By contrast, at $94 \%$ RH the MuAc concentration increased 4 -fold $\left(20^{\circ} \mathrm{C}, 21\right.$ days $)$ and the Erg concentrations increased 3 -fold $\left(30^{\circ} \mathrm{C}, 8\right.$ days $)$,

Table I: Microbial components in tobacco of cigarettes purchased in different countries.

\begin{tabular}{|c|c|c|c|c|c|c|}
\hline & & \multicolumn{2}{|c|}{ International brands } & \multicolumn{2}{|c|}{ Local brands } & \multirow{2}{*}{$\begin{array}{l}\text { p-value } \\
\text { Int-Loc }\end{array}$} \\
\hline & & min value & max value & min value & max value & \\
\hline \multirow[t]{4}{*}{ Sweden } & & & & & & \\
\hline & LPS & 11.7 & 21.0 & ns & ns & \\
\hline & MuAc & 3.8 & 8.5 & ns & ns & \\
\hline & Erg & 5.3 & 12.8 & ns & ns & \\
\hline \multirow[t]{4}{*}{ Poland } & & & & & & \\
\hline & LPS & 7.6 & 19.1 & 10.8 & 15.0 & \\
\hline & MuAc & 2.9 & 9.0 & 2.5 & 6.5 & \\
\hline & Erg & 2.0 & 10.2 & 6.2 & 9.9 & \\
\hline \multirow[t]{4}{*}{ Russia } & & & & & & \\
\hline & LPS & ns & Ns & 9.3 & 12.8 & \\
\hline & MuAc & ns & Ns & 2.7 & 9.4 & \\
\hline & Erg & ns & Ns & 6.0 & 7.9 & \\
\hline \multirow[t]{4}{*}{ China } & & & & & & \\
\hline & LPS & 7.0 & 15.2 & 7.2 & 8.2 & \\
\hline & MuAc & 7.0 & 7.4 & 2.0 & 2.3 & 0.000005 \\
\hline & Erg & 7.1 & 9.1 & 0.3 & 0.5 & 0.0002 \\
\hline \multirow[t]{4}{*}{ Korea } & & & & & & \\
\hline & LPS & 7.7 & 11.9 & 5.7 & 10.0 & \\
\hline & MuAc & 4.8 & 10.7 & 3.3 & 7.5 & \\
\hline & Erg & 5.7 & 9.3 & 2.2 & 4.2 & 0.005 \\
\hline \multirow[t]{4}{*}{ Vietnam } & & & & & & \\
\hline & LPS & 13.4 & 17.2 & 7.2 & 12.9 & 0.03 \\
\hline & MuAc & 3.7 & 6.8 & 1.4 & 6.3 & \\
\hline & Erg & 6.6 & 7.3 & 1.2 & 2.4 & 0.00001 \\
\hline
\end{tabular}

$\mathrm{ns}=$ not studied; LPS = lipopolysaccharides (pmol/mg); MuAc = muramic acid (ng/mg); Erg = ergosterol (ng/mg). 
Table 2: Microbial components in tobacco from light and full flavor cigarettes of an international brand purchased in five different countries.

\begin{tabular}{lcccccc}
\hline & \multicolumn{2}{c}{ Full flavor $(\mathrm{n}=5)$} & & \multicolumn{2}{c}{ Light $(\mathrm{n}=5)$} \\
\cline { 2 - 3 } \cline { 6 - 7 } & mean & SD & & mean & SD \\
\hline LPS & 12.04 & 2.57 & & 13.24 & 2.46 \\
MuAc & 6.74 & 0.68 & & 6.50 & 1.74 \\
Erg & 9.33 & 2.35 & & 8.58 & 1.33
\end{tabular}

LPS = lipopolysaccharides (pmol/mg); MuAc = muramic acid $(\mathrm{ng} / \mathrm{mg}) ;$ $\mathrm{Erg}=\operatorname{ergosterol}(\mathrm{ng} / \mathrm{mg})$.

18 -fold $\left(20^{\circ} \mathrm{C}, 21\right.$ days), and 16 -fold $\left(30^{\circ} \mathrm{C}, 21\right.$ days $)$ (Table 3, Figure 1). Cigarettes stored at $94 \%$ RH for 21 days exhibited a greenish colour from clearly visible mold growth.

\section{Smoke}

Tobacco with added E. coli cells contained approximately an 8-fold larger amount of LPS than tobacco without added bacteria (mean values 5.0 respectively $41.2 \mathrm{nmol} /$ cigarette); the increase in the mainstream smoke was approximately 4 -fold $(0.12$ v. $0.46 \mathrm{nmol})$. For MuAc the corresponding increases were 13 -fold (tobacco, mean values 3900 v. $50600 \mathrm{ng}$ ) and 7-fold (smoke, mean values 3.72 v. $25.7 \mathrm{ng}$ ). The amount of LPS and MuAc in the mainstream smoke from a cigarette was $2.4 \%$ and $0.1 \%$ respectively (control) and $1.1 \%$ and $0.05 \%$ respectively (spiked with E. coli) of the total amount in the cigarette (Table 4). Mainstream smoke from cigarettes that had been stored for 21 days at $94 \% \mathrm{RH}$, containing 15 times more Erg than cigarettes stored at low humidity, contained 9 times increased Erg concentration. The amount of Erg in the mainstream smoke from a cigarette was approximately $0.4 \%$ of the total amount in the cigarette (Table 5). See Figure 1.

\section{Tobacco leaves}

The concentrations of LPS (5.48-18.8 pmol/mg) and MuAc $(1.22-4.22 \mathrm{ng} / \mathrm{mg})$ in the studied leaves did not differ from those seen in cigarette tobacco regardless tobacco sort and stage of the curing. A very wide range $(0.79-74.4 \mathrm{ng} / \mathrm{mg})$ in the concentrations of Erg was found particularly among the F-samples. There was no consistent change of marker concentrations over time (Table 6).

Mesophilic bacteria dominated among the cultured microorganisms and were seen in all studied samples. Gram-negative bacteria and fungi were found in all fresh leaf samples and in approximately half of the cured leaf samples (Tables 7 and 8). Bacillus spp. and Gram-positive cocci were seen in most of the cured leaves (Table 9). A range of different bacterial and fungal species were occa- sionally found (Tables 10, 11 and 12), including Pantoea agglomerans (synonyms: Erwinia herbicola, Enterobacter agglomerans) which was most numerous among Gramnegative bacteria.

\section{Discussion}

Tobacco is an agricultural product rich in microorganisms that naturally colonize the tobacco plants [10]. We found that mesophilic bacteria dominated among the bacteria in both fresh and cured tobacco leaves but also that a wide range of other bacteria and fungi were present too. It is noteworthy that among Gram-negative bacteria recovered from tobacco leaves prevailed the species Pantoea agglomerans possessing strong endotoxic and allergenic properties [9]. This species represents probably one of the most important sources of endotoxin in tobacco. Interestingly, the bacterial biomass (MuAc) and LPS (3-OH FAs) concentrations in fresh tobacco leaves were in the same range as in the cured leaves and in the final tobacco product demonstrating that there is little enrichment of bacteria after the leaves are being collected at the plantation. By contrast, the concentrations of Erg varied dramatically especially between $\mathrm{V}$ - and B-samples, and between the different F-samples. The concentrations of the studied microbial components in the smoke were in general agreement with the concentrations in cigarette tobacco. Thus our results demonstrate that the microbiological material that is present in tobacco smoke originates from microorganisms that colonize the tobacco plants in the fields.

The microbial (marker) concentrations were much lower in some cigarettes locally produced in China, Korea, and Vietnam than in cigarettes of international brands purchased in the same countries. The reason for this finding is unknown; however, pesticides and fungicides - which would reduce microbial growth on the plants - are common on tobacco plantations. Indeed, pesticides have been identified in cigarette tobacco [11]. We found that storing cigarettes at $94 \%$ RH for 8 days or more may result in bacterial and, more pronounced, fungal growth in the cigarette tobacco; this may lead to increased concentrations of microbiological agents in the smoke. No differences in microbial load in "light" and "full flavor" cigarettes were found.

The endotoxin that is present in tobacco smoke may be responsible for some of the health effects of smoke. For example, it has been shown that asthmatics' symptoms are worsened in indoor environments that contain relatively larger concentrations of endotoxins [12]; interestingly, such symptoms are typically worsened also by exposure to tobacco smoke. The present study demonstrates that tobacco smoke contains bacterial components other than endotoxin as well as fungal components; indeed, aflatoxin B1 has been demonstrated in sidestream 

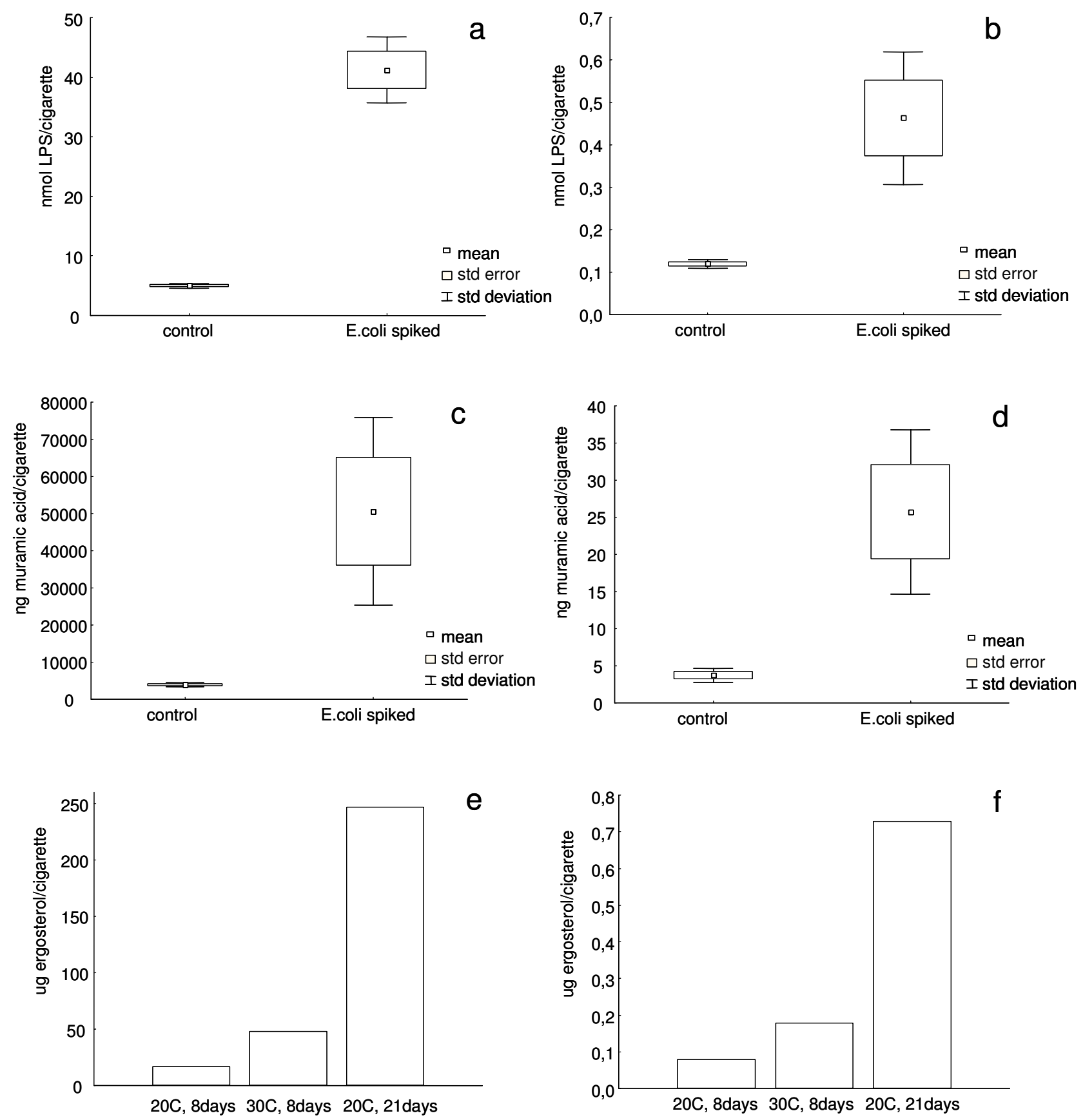

Figure I

Microbial components in tobacco (a, c, e) and smoke (b, $d, f)$ of cigarettes i) before and after adding a culture of $E$. coli to the tobacco (a-d), ii) after storing cigarettes at $94 \%$ relative humidity under different conditions (e, f). LPS = lipopolysaccharide. 
Table 3: Microbial components in tobacco of cigarettes of an international brand stored at different conditions.

\begin{tabular}{|c|c|c|c|c|}
\hline & & LPS & Erg & MuAc \\
\hline \multicolumn{5}{|l|}{ RH 54\% } \\
\hline \multirow[t]{2}{*}{2 days } & $20^{\circ} \mathrm{C}$ & 8.3 & 12.0 & 4.8 \\
\hline & $30^{\circ} \mathrm{C}$ & 8.6 & 11.9 & 5.2 \\
\hline \multirow[t]{2}{*}{8 days } & $20^{\circ} \mathrm{C}$ & 9.7 & 13.5 & 5.8 \\
\hline & $30^{\circ} \mathrm{C}$ & 9.3 & 12.4 & 3.2 \\
\hline \multirow[t]{2}{*}{21 days } & $20^{\circ} \mathrm{C}$ & 8.8 & 12.3 & 6.5 \\
\hline & $30^{\circ} \mathrm{C}$ & 7.2 & 14.8 & 5.0 \\
\hline \multicolumn{5}{|l|}{ RH 75\% } \\
\hline \multirow[t]{2}{*}{2 days } & $20^{\circ} \mathrm{C}$ & 9.8 & 17.2 & 5.3 \\
\hline & $30^{\circ} \mathrm{C}$ & 9.5 & 13.2 & 6.4 \\
\hline \multirow[t]{2}{*}{8 days } & $20^{\circ} \mathrm{C}$ & 9.8 & 19.0 & 5.4 \\
\hline & $30^{\circ} \mathrm{C}$ & 8.8 & 16.0 & 7.1 \\
\hline \multirow[t]{2}{*}{21 days } & $20^{\circ} \mathrm{C}$ & 8.7 & 14.1 & 6.8 \\
\hline & $30^{\circ} \mathrm{C}$ & 8.1 & 14.3 & 4.1 \\
\hline \multicolumn{5}{|l|}{ RH 94\% } \\
\hline \multirow{2}{*}{2 days } & $20^{\circ} \mathrm{C}$ & 7.6 & 15.1 & 4.4 \\
\hline & $30^{\circ} \mathrm{C}$ & 9.8 & 13.8 & 4.7 \\
\hline \multirow[t]{2}{*}{8 days } & $20^{\circ} \mathrm{C}$ & 9.3 & 16.8 & 4.8 \\
\hline & $30^{\circ} \mathrm{C}$ & 10.5 & 48.3 & 4.6 \\
\hline \multirow[t]{2}{*}{21 days } & $20^{\circ} \mathrm{C}$ & 6.2 & 272 & 19.7 \\
\hline & $30^{\circ} \mathrm{C}$ & 7.3 & 247 & 4.6 \\
\hline
\end{tabular}

LPS = lipopolysaccharides (nmol/cigarette); Erg = ergosterol ( $\mu \mathrm{g} /$ cigarette); $\mathrm{MuAc}=$ muramic acid $(\mu \mathrm{g} / \mathrm{cigarette}) ; \mathrm{RH}=$ relative humidity.

smoke [13]. Bacterial peptidoglycan, sometimes called the "endotoxin of Gram-positive bacteria"[14], is a potent entity that use Toll-like receptor (TLR)-2 for cell binding and activation of the innate immunity response (endotoxin uses TLR-4); inhalation of dust containing elevated concentrations of peptidoglycan or fragments thereof has been shown to result in fever and increased levels of blood interleukin-6 [15].

Table 4: Bacterial components in tobacco and smoke collected from cigarettes spiked/not spiked by a suspension of $E$. coli.

\begin{tabular}{cccccc}
\hline & \multicolumn{2}{c}{ Tobacco } & & \multicolumn{2}{c}{ Smoke } \\
\cline { 2 - 3 } \cline { 5 - 6 } \cline { 5 - 6 } & control & E. coli spiked & & control & E. coli spiked \\
\hline \multirow{4}{*}{ LPS } & 4.91 & 46.7 & & 0.13 & 0.63 \\
& 5.45 & 35.6 & & 0.11 & 0.44 \\
& 4.63 & 41.4 & & 0.12 & 0.32 \\
MuAc & 4120 & 79600 & & 3.94 & 37.4 \\
& 3270 & 39000 & & 4.54 & 24.4 \\
& 4310 & 33300 & & 2.69 & 15.4
\end{tabular}

LPS = Lipopolysaccharides (nmol/cigarette); MuAc = muramic acid (ng/cigarette).
Table 5: Ergosterol in tobacco and smoke from cigarettes after storage at $\mathbf{9 4 \%} \mathbf{R H}$.

\begin{tabular}{|c|c|c|}
\hline \multirow[b]{2}{*}{ Storage } & \multicolumn{2}{|c|}{ Erg } \\
\hline & Tobacco & Smoke \\
\hline $20^{\circ} \mathrm{C}, 8$ days & 16.8 & 0.08 \\
\hline $30^{\circ} \mathrm{C}, 8$ days & 48.3 & 0.18 \\
\hline $30^{\circ} \mathrm{C}, 2 \mathrm{I}$ days & 247 & 0.73 \\
\hline
\end{tabular}

Erg $=$ ergosterol $(\mu \mathrm{g} /$ cigarette)

In conclusion, tobacco smoke is a bioaerosol that contains endotoxin, peptidoglycan or peptidoglycan fragments, and various fungal constituents. This knowledge may help to explain the high prevalence of respiratory disorders such as bronchoalveolar neutrophilia, airway obstruction, and bronchial hyperresponsiveness among smokers and individuals exposed to second hand smoke, since these symptoms are also commonly associated with exposure to bioaerosols [16-19]. Public awareness that tobacco smoke contains high concentrations of bacterial and fungal constituents may contribute to reduce smoking.

\section{Authors' contributions}

LL designed the study and did the main writing. BS and JD were responsible for the samplings and microbiological analyses. CP and BR made the chemical analyses and EK and JS made the culturing and microbiological analyses. All authors participated in the writing.

Table 6: Microbial components in tobacco leaves collected from a tobacco plantation and a tobacco manufacturing plant.

\begin{tabular}{lccc}
\hline Origin of tobacco leaf & LPS & MuAc & Erg \\
\hline F-I & 6.07 & 1.68 & 0.79 \\
F-2 & 7.97 & 4.22 & 74.4 \\
F-3 & 8.20 & 2.08 & 54.4 \\
F-4 & 9.52 & 2.45 & 12.3 \\
V-I & 6.44 & 1.92 & 2.03 \\
V-2 & 7.03 & 2.13 & 1.73 \\
V-3 & 7.36 & 1.73 & 1.95 \\
B-I & 7.66 & 1.22 & 52.4 \\
B-2 & 6.66 & 1.72 & 10.9 \\
B-3 & 8.68 & 3.40 & 39.2 \\
K-1 & 10.97 & 1.77 & 16.7 \\
K-2 & 10.67 & 2.19 & 10.2 \\
K-3 & 7.87 & 1.67 & 2.9 \\
SM-I & 5.48 & 1.44 & 14.5 \\
SM-2 & 18.8 & 2.95 & 35.0 \\
SM-3 & 7.51 & 1.71 & 15.5 \\
& & & \\
\hline
\end{tabular}

LPS = lipopolysaccharide (pmol/mg); MuAc = muramic acid $(\mathrm{ng} / \mathrm{mg})$; $\mathrm{Erg}=$ ergosterol $(\mathrm{ng} / \mathrm{mg}) ; \mathrm{F}=$ samples from a tobacco plantation: Fresh leaves ( $\mathrm{F}-\mathrm{I})$, and leaves after $2 \mathrm{wk}(\mathrm{F}-2), 6 \mathrm{wk}(\mathrm{F}-3)$, and $>6 \mathrm{wk}$ (F-4) of curing; $V=$ Virginia; $B=$ Burley; $K=$ Kentucky; $S M=$ Skroniowski Mocny; I = air-dried leaves; 2 = leaves after curing; 3 = leaves after curing and storage $>$ I year. 
Table 7: Microorganisms in tobacco leaves (CFU × $\left.10^{3} / \mathrm{g}\right)$ collected from a tobacco plantation.

\begin{tabular}{|c|c|c|c|c|}
\hline & F-I & F-2 & F-3 & F-4 \\
\hline Total mesophilic bacteria & 2.0 & 2.4 & 3.3 & 6.6 \\
\hline Gram-negative bacteria & 0.4 & 0.5 & 1.0 & 2.0 \\
\hline Fungi & 0.3 & 0.3 & 1.3 & 2.6 \\
\hline
\end{tabular}

$\mathrm{F}=$ samples from a tobacco plantation: Fresh leaves (F-I), and leaves after 2 wk (F-2), 6 wk (F-3), and > 6 wk (F-4) of curing

Table 8: Microorganisms in tobacco leaves (CFU × $\left.10^{3} / \mathrm{g}\right)$ collected from a tobacco manufacturing plant.

\begin{tabular}{lcccccccccccc}
\hline & V-I & V-2 & V-3 & B-I & B-2 & B-3 & K-I & K-2 & K-3 & SM-I & SM-2 & SM-3 \\
\hline Total mesophilic bacteria & $38 I$ & 102.5 & 8 & 2 & 680 & 155 & 1 & 33 & 11 & 328 & 556.5 & 9 \\
Gram-negative bacteria & 145 & 19.5 & 0 & 0 & 0 & 38.5 & 0 & 0 & 0 & 150 & 415 & 0 \\
Thermophilic actinomycetes & 0.5 & 0 & 0 & 0 & 0 & 0 & 0 & 0 & 0 & 0.5 & 1.5 & 2 \\
Fungi & 0 & 7 & 0.5 & 1 & 0 & 0 & 6.5 & 3.5 & 0 & 1 & 8 & 0
\end{tabular}

$\mathrm{V}=$ Virginia; $\mathrm{B}=$ Burley; $\mathrm{K}=$ Kentucky; $\mathrm{SM}=$ Skroniowski Mocny; I = air-dried leaves; 2 = leaves after curing; 3 = leaves after curing and storage > I year.

Table 9: Mesophilic bacteria in tobacco leaves (CFU $\times 10^{3} / \mathrm{g}$ ) collected from a tobacco manufacturing plant.

\begin{tabular}{|c|c|c|c|c|c|c|c|c|c|c|c|c|}
\hline & V-I & $V-2$ & V-3 & B-I & B-2 & B-3 & K-I & K-2 & K-3 & SM-I & SM-2 & SM-3 \\
\hline Gram-negative bacteria & 325 & 20 & 0 & 0 & 0 & 17 & 0 & 0 & 0 & 200 & 510 & 0 \\
\hline Gram-positive cocci & 5 & 2.5 & 1.5 & 1.5 & 0 & 0 & 0.5 & 0 & I & 10 & 10 & 0 \\
\hline Endospore-forming bacilli & $15^{b}$ & $75.5^{\mathrm{a}}$ & $6.5^{b}$ & $0.5^{b}$ & $680^{a}$ & $\left.||\right|^{a, b}$ & $0.5^{b}$ & $33^{b}$ & $10^{\mathrm{b}}$ & $6.5^{\mathrm{b}}$ & $30^{b}$ & $9 b$ \\
\hline Coryneform bacteria & $35^{c, d}$ & 0 & 0 & 0 & 0 & $27 \mathrm{e}$ & 0 & 0 & 0 & $108^{\mathrm{d}, \mathrm{e}}$ & If $^{\prime}$ & 0 \\
\hline Mesophilic actinomycetes & $1 \mathrm{~g}$ & $4.5 \mathrm{~g}$ & 0 & 0 & 0 & 0 & 0 & 0 & 0 & $3.5 \mathrm{~g}, \mathrm{~h}$ & $5.5 \mathrm{~g}, \mathrm{~h}$ & 0 \\
\hline Total & 381 & 102.5 & 8 & 2 & 680 & 155 & I & 33 & I I & 328 & 556.5 & 9 \\
\hline
\end{tabular}

V = Virginia; $B=$ Burley; $K=$ Kentucky; SM = Skroniowski Mocny; I = air-dried leaves; 2 = leaves after curing; 3 = leaves after curing and storage > I year.

aBacillus subtilis, bBacillus spp., ${ }^{\mathrm{C} A r t h r o b a c t e r ~ i l i c i s, ~}{ }^{\mathrm{d} C u r t o b a c t e r i u m ~ p u s i l l u m, ~ e S a n g u i b a c t e r ~ i n u l i n u s, ~}{ }^{\mathrm{f}}$ Arcanobacterium pyogenes, 8 Streptomyces albus,

hStreptomyces spp.

Table 10: Gram-negative bacteria in tobacco leaves (CFU $\times 10^{3} / \mathrm{g}$ ) collected from a tobacco manufacturing plant.

\begin{tabular}{|c|c|c|c|c|c|c|c|c|c|c|c|c|}
\hline & V-I & V-2 & V-3 & B-I & B-2 & B-3 & K-I & K-2 & K-3 & SM-I & SM-2 & SM-3 \\
\hline Pantoea agglomerans & 145 & 3 & 0 & 0 & 0 & 6 & 0 & 0 & 0 & 90 & 405 & 0 \\
\hline Other Enterobacteriaceae species & 0 & $16.5^{b, c}$ & 0 & 0 & 0 & $15.5^{\mathrm{a}}$ & 0 & 0 & 0 & 0 & 0 & 0 \\
\hline Acinetobacter calcoaceticus & 0 & 0 & 0 & 0 & 0 & 9 & 0 & 0 & 0 & 0 & 0 & 0 \\
\hline Pseudomonadaceae species & 0 & 0 & 0 & 0 & 0 & $8 \mathrm{e}, \mathrm{f}$ & 0 & 0 & 0 & $60^{f, g}$ & $10^{d}$ & 0 \\
\hline Total & 145 & 19.5 & 0 & 0 & 0 & 38.5 & 0 & 0 & 0 & 150 & 415 & 0 \\
\hline
\end{tabular}

V = Virginia; $\mathrm{B}=$ Burley; $\mathrm{K}=$ Kentucky; SM = Skroniowski Mocny; I = air-dried leaves; 2 = leaves after curing; 3 = leaves after curing and storage > I year.

aButtiauxella brennerae, bEnterobacter amnigenus, ${ }^{\mathrm{C} E n t e r o b a c t e r ~ c a n c e r o g e n u s, ~ d P s e u d o m o n a s ~ f l u o r e s c e n s, ~ e P s e u d o m o n a s ~ v i r i d i l i v i d a, ~}{ }^{\mathrm{f} S}$ Phingomonas paucimobilis, 8 Stenotrophomonas maltophilia. 
Table II: Thermophilic actinomycetes in tobacco leaves (CFU $\left.\times 10^{3} / \mathrm{g}\right)$ collected from a tobacco manufacturing plant.

\begin{tabular}{|c|c|c|c|c|c|c|c|c|c|c|c|c|}
\hline & V-I & V-2 & V-3 & B-I & B-2 & B-3 & K-I & K-2 & K-3 & SM-I & SM-2 & SM-3 \\
\hline Thermoactinomyces thalpophilus & 0 & 0 & 0 & 0 & 0 & 0 & 0 & 0 & 0 & 0.5 & 0 & 2 \\
\hline Thermoactinomyces vulgaris & 0.5 & 0 & 0 & 0 & 0 & 0 & 0 & 0 & 0 & 0 & 1.5 & 0 \\
\hline Total & 0.5 & 0 & 0 & 0 & 0 & 0 & 0 & 0 & 0 & 0.5 & 1.5 & 2 \\
\hline
\end{tabular}

V = Virginia; $\mathrm{B}=$ Burley; $\mathrm{K}=$ Kentucky; SM = Skroniowski Mocny; I = air-dried leaves; 2 = leaves after curing; $3=$ leaves after curing and storage > I year.

Table 12: Fungi in tobacco leaves (CFU $\left.\times 10^{3} / \mathrm{g}\right)$ collected from a tobacco manufacturing plant.

\begin{tabular}{|c|c|c|c|c|c|c|c|c|c|c|c|c|}
\hline & V-I & $V-2$ & $V-3$ & B-I & B-2 & B-3 & K-I & $K-2$ & K-3 & SM-I & SM-2 & SM-3 \\
\hline Aspergillus spp. & 0 & $5.5^{\mathrm{a}, \mathrm{b}, \mathrm{c}}$ & 0 & 0 & 0 & 0 & $4^{d}$ & 0 & 0 & $\left.\right|^{a, b}$ & 0 & 0 \\
\hline Other fungi & 0 & $1.5^{f, j}$ & $0.5 \mathrm{~g}$ & $\mathrm{I}^{\mathrm{h}}$ & 0 & 0 & $2.5^{\mathrm{e}, \mathrm{I}}$ & $3.5^{k}$ & 0 & 0 & $8^{i}$ & 0 \\
\hline Total & 0 & 7 & 0.5 & I & 0 & 0 & 6.5 & 3.5 & 0 & I & 8 & 0 \\
\hline
\end{tabular}

V = Virginia; $\mathrm{B}=$ Burley; $\mathrm{K}=$ Kentucky; SM = Skroniowski Mocny; I = air-dried leaves; 2 = leaves after curing; 3 = leaves after curing and storage > I year.

aAspergillus fumigatus, bAspergillus glaucus, cAspergillus niger. ${ }^{\mathrm{A} A s p e r g i l l u s ~ p e n i c i l l o i d e s, ~ e A l t e r n a r i a ~ a l t e r n a t a, ~}{ }^{\mathrm{f} C l a d o s p o r i u m ~ h e r b a r u m, ~ g O i d i o d e n d r o n ~ c i t r i n u m, ~}$

hPenicillium brevi-compactum, iPenicillium spp., iRhizopus nigricans, kRhodotorula rubra, 'Yeasts (white colonies).

\section{Acknowledgements}

This work was supported by the Flight Attendant Medical Research Institute (FAMRI). Lars Wadsö is acknowledged for help with cigarette exposure to different humidities and temperatures.

\section{References}

I. Hasday JD, Bascom R, Costa JJ, Fitzgerald T, Dubin W: Bacterial endotoxin is an active component of cigarette smoke. Chest 1999, I I 5:829-835.

2. Larsson L, Szponar B, Pehrson C: Tobacco smoking increases dramatically air concentrations of endotoxin. Indoor Air 2004, I4:42I-424.

3. Sebastian A, Pehrson C, Larsson L: Elevated concentrations of endotoxin in indoor air due to cigarette smoking. Journal of Environmental Monitoring 2006, 8:519-522.

4. Schwartz DA, Thorne PS, Yagla SJ, Burmeister LF, Olenchock SA, Watt JL, Quinn TJ: The role of endotoxin in grain dust-induced lung disease. American Journal of Respiratory and Critical Care Medicine 1995, I 52:603-608.

5. Wilkinson S: Gram negative bacteria. Edited by: Wilkinson S, Ratledge C. Microbial lipids, Academic Press, New York; 1988:299-488.

6. Sebastian A, Larsson L: Characterisation of the microbial community in indoor environments: a chemical-analytical approach. Applied and Environmental Microbiology 2003, 69:3103-3109.

7. Sebastian A, Szponar B, Larsson L: Characterisation of the microbial community in indoor environments by chemical marker analysis: an update and critical evaluation. Indoor Air 2005, I 5(Suppl 9):20-26.

8. Nyqvist $\mathrm{H}$ : Saturated salt solutions for maintaining specified relative humidities. International Journal of Pharmaceutical Technology and Product Manufacture 1983, 4:47-48.

9. Skórska C, Sitkowska J, Krysiñska-Traczyk E, Cholewa G, Dutkiewicz $\mathrm{J}$ : Exposure to airborne microorganisms, dust and endotoxin during processing of peppermint and chamomile herbs on farms. Annals of Agricultural and Environmental Medicine 2005, 1 2:28I-288.

10. Beattie G, Lindow S: Bacterial colonization of leaves: a spectrum of strategies. Phytopathology 1999, 89:353-359.

II. Zhang X, Cheng X, Wang C, Xi Z, Li Q: Efficient high-performance liquid chromatography with liquid-liquid partition cleanup method for the determination of pymetrozine in tobacco. Annali di Chimica 2007, 97:295-30I.

12. Michel O, Kips J, Duchateau J, Vertongen F, Robert L, Collet H, Pauwels R, Sergysels R: Severity of asthma is related to endotoxin in house dust. American Journal of Respiratory and Critical Care Medicine 1996, I54:1641-1646 [http://ajrccm.atsjournals.org/cgi/content/ abstract/I54/6/164I].

13. Edinboro LE, Karnes HT: Determination of aflatoxin B I in sidestream cigarette smoke by immunoaffinity column extraction coupled with liquid chromatography/mass spectrometry. Journal of Chromatography A 2005, 1083: 127-132.

14. Chetty C, Schwab ]: Endotoxin-like products of gram-positive bacteria. In Handbook of Endotoxin. Chemistry of endotoxin Volume I. Edited by: Rietschel ETh. Amsterdam: Elsevier Scientific Publishing; 1984:376-4I0.

15. Zhiping W, Malmberg P, Larsson B-M, Larsson K, Larsson L, Saraf A: Exposure to bacteria in swine-house dust and acute inflammatory reactions in humans. American Journal of Respiratory and Critical Care Medicine 1996, 154:126I-1266 [http://ajrccm.atsjour nals.org/cgi/content/abstract//54/5/|26I].

16. Park JH, Gold DR, Spiegelman DL, Burge HA, Milton DK: House dust endotoxin and wheeze in the first year of life. American Journal of Respiratory and Critical Care Medicine 200I, 163:322-328.

17. Heldal KK, Halstensen AS, Thorn J, Eduard W, Halstensen TS: Airway inflammation in waste handlers exposed to bioaerosols assessed by induced sputum. European Respiratory Journal 2003 , 21:64I-645.

18. Dangman $\mathrm{KH}$, Bracker AL, Storey E: Work-related asthma in teachers in Connecticut: association with chronic water damage and fungal growth in schools. Connecticut Medicine 2005, 69:9-17.

19. Menzies D, Comtois P, Pasztor J, Nunes F, Hanley JA: Aeroallergens and work-related respiratory symptoms among office workers. Journal of Allergy and Clinical Immunology 1998, 101:38-44. 